contributed to the decline of the Muslim world - by way of invasion, colonisation, and division. Rather naïvely, Chapra seems to believe that the Western world could 'help' the Muslim world to restore its lost glory. He offers his gratitude to the West for what he describes as its 'humanitarian' help to the Muslim world. He seeks to apologetically admonish the West for the damage that its adventures are causing in Iraq and Afghanistan and its support for Israeli aggression in Lebanon and Palestine. His attempt in this section simply reveals his poor comprehension of international relations and politics of international development.

On the other hand, Chapra has done a good job in kindling a lively debate on the important issue of diagnosing the ailments of the Muslim world and prescribing alternative solutions. However, the reader would have expected him to cite and criticise other works that have also focused on the causes of decline in Muslim civilisation and the need for reform. As a matter of fact, Chapra does mention a few works cursorily. However, those works offer no comprehensive diagnosis on the problems confronting Muslims today. Likewise, the author could have substantiated why the reader should believe in his suggestions as to how the Muslim world could regain its glory. Reference to other comparative sources could have helped the reader to know what others prescribe as solution, what are the similarities and differences in their argument, and why the author's recommendations should be taken seriously. In similar vein, Chapra should have tried to offer an evaluation of the contemporary attempts by reformist groups in the Muslim world and should have presented some of the lessons from their various approaches. Chapra should have offered an in-depth critique of the different approaches. The limited space he devotes to Islamic movements is largely descriptive and presents rather unsubstantiated recommendations. Likewise, the reader misses an in-depth examination on whether the historical decay in Muslim civilisation was purely an inside factor or the result of other external forces such as Western intervention. The author is also silent on the effects that other important issues, such as the 'war on terror', can have on Islamic revivalism. In spite of those and other similar shortcomings, however, Chapra's book should be considered an important contribution in the current 'revival of Islamic civilisation debate'.

\title{
Muhammad Arif Zakaullah - The Cross and the Crescent: The Rise of American Evangelicalism and the Future of Muslims
}

(Kuala Lumpur: The Other Press, 2004), paperback, xii + 269 pp. ISBN 983-9541-42-0

\section{N. Doran Hunter Minnesota State University at Mankato, United States}

Socrates, the great Athenian philosopher, once said that self-regard, self-knowledge and self-control would lead men to sovereign power. The idea was that through 
understanding human nature one could determine how to live with others in successful communities, celebrating the unique qualities found in each human being, and recognising that sometimes individual interest must bow to the greater good. Thomas Hobbes, the English philosopher, wrote that persons should not do to others what they would not want others to do to them. The eighteenth-century German philosopher Immanuel Kant developed the concept of the categorical imperative, which states that individuals when considering a particular act that could impact others should also consider what the consequences would be if all others engaged in the same act. Rollo May, the psychologist, tells us that the truly mature human being is one who honours his or her talents and abilities, and puts these attributes in service to others, while at the same time honouring the talents and abilities found in others. One could argue that upon these basic concepts rest all flourishing and thriving human relationships.

Scott Gordon, a political philosopher and historian, has written that these basic principles and values are meaningless unless actualised through a strong nation-state with functioning and robust institutions and processes. Such a nation-state would provide safety and security for its members, do for the citizens what they could not do for themselves, operate within the framework of a constitution and the rule of law, create the means for citizens to make collective decisions on matters of general interest, establish a system of courts where the government and individual persons can plead cases before independent judges who have the authority to make binding decisions, and assure that the governors exercise authority under law and not act arbitrarily. Thus, it is within a stable and peaceful nation-state, following these basic institutions and processes, that it does become possible for human relationships to flower and for human potential to be realised.

David Landis, an historian of economic systems, and Thomas Friedman, a journalist, have both suggested that material progress is essential for any successful nation-state. Their research demonstrates that material progress is a product of a strong private sector, low rates of inflation, balanced budgets and price stability, low tariffs, allowing foreign investment, getting rid of monopolies, deregulating capital markets, making currency convertible, hiring and promoting on the basis of merit and competence, and increasing domestic competition. Governments should also eliminate corruption, create a strong educational system, promote gender equality, and assure the rights of property. An impoverished nation-state will not allow its citizens to achieve their potential and it will not foster the kind of institutions and processes that are critical to a healthy, stable and successful community.

In the book under review here, Zakaullah, an American-trained Muslim economist and a professor of economics at the International Islamic University of Malaysia, investigates American Christian fundamentalism and its impact upon the American political system, and how that impact might affect relations between the Western 
world and the Muslim world. The book itself is a treasure trove of statistics and analyses of American elections and religious predispositions. The research is exhaustive in many areas of interest, and the insights into the American political mind are probing and suggestive. It is the salubrious professional attitude that Zakaullah brings to his research and writing, however, that sets the book apart from the many other efforts to compare and contrast the Western and Muslim worlds. He is wise in rejecting the Orientalist approach to his subject because of its inherent bias against anything non-western, its lack of scientific rigour and because he believes that the conflicts between these two worlds can only be resolved through scientific (empirical) studies of the issues involved. Dialogue based on empirical data, informed by universal ethical principles, and supported by religious and political leaders of good will can resolve issues that divide human beings.

Zakaullah begins his book by analysing the American 2000 presidential elections. The central question for him is why, given the excellent economy under President Bill Clinton, did his Vice President, Al Gore, lose the election to the Texas governor, George W. Bush? He looks at previous presidential elections and determines that when the economy is good the incumbent party usually retains the White House. His answer is that the phenomenon of 'meta-economics' intervened, an interesting concept that suggests there are larger forces at work during a presidential election than just economics or more mundane things. These larger forces had to do with rudimentary changes in the American political landscape that began to take shape in the 1960s beginning with the emergence of Christian fundamentalism and evangelicalism in the American south, which transformed southern political majorities from supporting the Democratic Party to the Republican Party. With the failure of the second term of President Richard Nixon, and the emergence of personal character and trustworthiness as meta-economic issues, the southern voter tended to look for presidential candidates who were not tainted by scandal or immoral behaviour, and it seems that the sexual licentiousness of President Bill Clinton, along with other improprieties, rubbed off on his vice president, with the southern voter rejecting $\mathrm{Al}$ Gore as a candidate too closely associated with the stain of a seemingly unprincipled incumbent.

After discussing the concept of meta-economics and the presidential elections of 2000, Zakaullah looks to see how Christianity impacts politics in America. He analyses the contributions of Martin Luther and John Calvin to the American character and how Protestantism led to the American ethic of hard work, individualism, selfdiscipline, and personal honesty and diligence. He recognises that the twentieth century brought a division within Protestantism with liberal theologians questioning the fundamentals of the 'old time religion' and Christian conservatives fighting back by confirming the fundamentals of their religion: the inerrancy of Scripture, the divinity of Christ, the virgin birth of Jesus, the purpose of the Cross and the bodily 
resurrection of Jesus, and the Second Coming of Christ. With the battle lines set, the Midwest and the southern parts of America kept faith with the basics of Christianity while other parts of America divided religious allegiances.

During the second half of the twentieth century, with US Supreme Court decisions on civil rights, abortion, and school prayer challenging the moral and religious views of fundamentalist Christians; the emergence of fiery, fundamentalist preachers (Billy Graham, Pat Robertson, Oral Roberts, Jerry Falwell); the successful candidacy of 'born again' President Jimmy Carter; and the two term presidencies of Christian conservatives Ronald Reagan and George W. Bush, it seemed that Christian fundamentalism had won the political day. No presidential candidate could lose the southern states and a number of states in the Midwest and then garner the electoral votes necessary to win the American presidency. To win those sections of America, along with the Rocky Mountain states, assures a successful presidential candidacy. And it appears that successful presidential candidates must be, at least most of the time, republicans or middle of the political road democrats who carry the banners of fundamentalist Christianity.

If America is becoming more conservative, and that conservatism is embossed with Christian fundamentalism, what impact will that phenomenon have on the Muslim world? Zakaullah presents an in-depth look at Millennialism as the core belief of contemporary Christian fundamentalists. This belief system is grounded on the Book of Revelation found in the New Testament of the Bible. Millennialists interpret this scripture as foretelling the following events during the last days of the world: prior to the end of the world there will be a series of cataclysmic events and these events have already started; prior to or at the end of 1,000 years, Christ will literally and bodily come back to earth to reign with glory, depending on your interpretation of the New Testament's Book of Revelation; and all sinners will be banished from a coming paradise with all believers in Christ reigning with him for eternity. Of course, there are many variations on this theme from a very conservative point-of-view to the interpretation that says the whole Book of Revelation is allegory and not to be taken literally. This belief system becomes an important point of departure, however, because if a substantial portion of the American electorate really believes this foretelling, and they have some control over presidential elections, then public policy could, however tangentially, be affected by this apocalyptic vision.

Of course, with the two major wars of the twentieth century, the doctrine of 'Mutually Assured Destruction' (nuclear war), weapons of mass destruction (chemical and biological weapons), the creation of the State of Israel, the war in Babylon (Iraq), the coming resource crisis, and the radicalisation of important parts of the Muslim world, some religious leaders, many politicians, and leading intellectuals see a 'clash of civilisations' looming in the future of the human race. Almost all of the important events in current world history are interpreted by 
Christian fundamentalists as either precursors for or explanations of the events foretold in the Book of Revelation. The question Zakaullah asks is what will this ominous and momentous perspective have on the political and economic relationship between Christian America and the Muslim world?

The answer Zakaullah gives to the question involves the need for Muslim countries to create scientific research programmes and institutions in order to understand Christian America and her politics, economics, and cultural institutions and ideologies. Specifically, the Muslim world needs to create three world-class think tanks, "one focused on the United States, the other on the European Union, while the third think tank would focus on Judaism and Israel". These institutions should be well funded and staffed with the best scholars of international note. Think tanks specialising in other countries and parts of the world are also envisioned. The research agenda for these think tanks would include the following issues: the nature of Western liberal democracies and their internal socio-economic and ethnocultural sensitivities; the historical, economic, and social trends in other societies and the reasons for them; understanding Western media and how they work; study "contemporary ideological forces and movements in the West and try to analyse their implications" for the Muslim world; and study why there is such negative reaction and condemnation of the West by Muslim nations. The studies produced by these research institutions should be widely distributed by Muslim media and other sources of information. Beyond these new institutions, Muslim universities should establish programmes in Western and Eastern studies. It is through education and understanding that a 'clash of civilisations' can be avoided and mutual respect among peoples established.

If one studies the seven great world faith traditions one is impressed that all profess the same body of basic moral principles and ethical practices. If one also studies the great secular philosophers of the Greek, Roman, English, Scottish, and American enlightenment periods one is also informed that, with a few exceptions, these philosophers would agree to the same basic moral and ethical codes. If one looks at the Eastern ethical and moral traditions of Confucius and the Buddha one learns the same principles of basic moral behaviour and ethical conduct as taught by traditional religious and secular leaders. In other words, there seems to be a form of agreement among most human beings, no matter what their religious preferences or secular philosophical predispositions, that certain forms of human conduct are appropriate and other forms are not. Christian fundamentalism may have a view of the coming Apocalypse but the rules of human conduct towards others are stated clearly in the New Testament of the Bible. Other faith traditions have views pertaining to the end of human history but their codes of human conduct towards others are explicit and understandable. Beyond principles of human conduct we also know, based on the information stated above, how to produce material prosperity for 
a nation-state and what kinds of civil and governmental institutions and processes are necessary for successful group life. So, what's the problem?

Most scholars analyse a problem brilliantly and then offer solutions that are manifold but not particularly efficacious to the problem addressed. Zakaullah does not fall into this trap. While not specifically answering the question concerning the relationship between American Christian fundamentalism and politics and its impact on the Muslim world, he does give us the institutional framework for answering the question. He recognises, along with John Stuart Mill, that an open-ended study of the problems that face a society, learning from many sources, using empirical research to understand problems and the possible solutions to them, opening young minds to the possibilities of the future, and interacting with 'the other', is the only way to achieve a peaceful and orderly world. 